\title{
MENEKÜLTKÉPEK
}

DOI: http://dx.doi.org/10.17355/rkkpt.v24i4.135

FEISCHMIDT MARGIT*

\section{Manipulált félelmek és dehumanizált idegenek}

\section{A xenorasszizmus felépítése és társadalmi háttere egy magyarországi faluban}

\section{Kutatási kérdések és módszerek}

\begin{abstract}
magyar társadalomnak az idegenekhez való viszonyát elsősor1 ban kvantitatív vizsgálatokból ismerjük. ${ }^{1}$ A Tárki húsz éve rendszeresen méri az idegenekkel kapcsolatos alapattitüdöket három kategória mentén: aszerint, hogy mindenkit befogadjunk-e, senkit sem vagy mérlegeljünk, hogy kit fogadjunk be. Az így mért idegenellenesség a 2014-es, átlagosnak tekintett szinthez képest jelentős mértékben növekedett. A mérlegelök aránya csökkent, az úgynevezett idegenbarátoké pedig 2016-ra a mérhetőség minimális szintjére (1\%) került. ${ }^{2}$

Mi arra tettünk kiséletet, hogy a kvalitatív módszereket is bevonjuk az idegenekkel kapcsolatos félelem és elutasítás vizsgálatába. A xenofóbia dinamikáját - létrejöttét, fennmaradását és változásait a diskurzusok és (elsősorban a lokális) társadalmi viszonyok kontextusában akartuk megérteni. A vizsgálat középpontjában két település állt, amelyek a szerb-magyar határ két oldalán helyezkednek el az ún. balkáni útvonal közelében. Közülük ebben a tanulmányban csak az egyikről lesz szó, Ásotthalomról. A határ
\end{abstract}

\footnotetext{
* A szerző az MTA TK Kisebbségkutató Intézetének tudományos főmunkatársa. E-mail: feischmidt.margit@tk.mta.hu

A kutatás az MTA Társadalomtudományi Kutatóközpont Társadalmi konfliktusokra adott identitáspolitikai válaszok címủ Inkubátor programja keretében készült.

${ }^{2}$ Forrás: Tárki Omnibusz 2014-2016.
} 
szerbiai oldalán fekvő Királyhalomról Szerbhorváth György ír egy másik tanulmányban. A két település kiválasztása mellett több fontos érv szólt: a 2015-ös nemzetközi vándorlás általi érintettségük, a határ közeliségből adódó korábbi hasonló emlékek, és nem utolsó sorban a településekre irányuló politikai és médiafigyelem. Különböző szereplök százezer körülire becsülték azoknak a nemzetközi vándoroknak a számát, akik 2015 során kisebb-nagyobb csoportokban áthaladtak a falun. Ez egyfelöl bizonytalanságot, sőt, mint majd látni fogjuk, félelmet szült az ott lakó nem egészen ötezer emberben, másfelöl számos ellenkező hatással járó hétköznapi találkozásra adott lehetöséget.

A kutatás alapkérdése tehát az volt, hogy a menekülőket miként érzékelték Magyarországon egy olyan helyen, ahol az érzékelésben és a reakciók megfogalmazásában a politika, a média és a hétköznapi találkozások egyaránt szerepet játszottak. A jelenséget nem a közvélemény vagy a szociálpszichológiai attitüdök, hanem a társadalmi diskurzusok felöl közelítjük meg. Kiindulópontunk az idegeneket jelentéssel felruházó társadalmi diskurzusok leírása, amely diskurzusokat két dimenzióban, a hétköznapi beszédben és a nyilvánosságban, azon belül a politikában és a közösségi médiában igyekeztünk megragadni. A leírás interjúkra, etnográfiai megfigyelésre, egy körülbelül kéthetes terepmunkára és online etnográfiára támaszkodik.

Az elemzés három perspektívát alkalmaz és kapcsol össze:

(1) egy diszkurzív megközelítést, amellyel a félelem genezisét, az idegenek rasszizálását és dehumanizációját a hétköznapi beszédmódokon keresztül igyekeztünk megérteni;

(2) egy antropológiai megközelítést, amellyel a lokális, nemzeti és transznacionális aktorok müködését és kölcsönhatásait vizsgáltuk a biztonságosítás területén; és végül

(3) egy strukturális megközelítést, amellyel az első kettő, a xenofóbia diskurzusainak és a radikális jobboldali politika támogatottságának magyarázatára törekedtünk. 
Biztonságosítás, xeno-rasszizmus és az idegenek dehumanizációjának diskurzusai

A diskurzusok szerepére az idegenektől való félelem megteremtésében és terjesztésében a szélsőjobboldali politikával, a rasszizmus új formáival és a biztonság kérdéseivel foglalkozó kutatások egyaránt felhívták a figyelmet az elmúlt években. A biztonságosítás (securitization) irodalma a nemzetközi kapcsolatok és a politikai folyamatok kutatásába egy eredendően nyelvészeti paradigmát, a beszédaktus elméletet hozta be. Ez a biztonság és vele együtt a félelem diszkurzív felépítését hangsúlyozza, amely az uralom kialakításának, kiterjesztésének és megerősítésének elsősorban a szélsőjobboldali pártok és mozgalmak által alkalmazott, de a közbeszéd és a politika fóáramába is mindinkább bekerülő stratégia. A biztonságosítás - amiként arra a témában immár klasszikusnak számító Koppenhágai Iskola - felhívta a figyelmet, azt jelenti, hogy különböző témák válhatnak biztonságpolitikai kérdéssé, amelyek ezáltal kikerülnek a politika szokványos menetéből, és rendkívüli, „válság”-megoldásokat tesznek lehetővé. ${ }^{3}$ A média által ezek a témák még inkább performatív erejűvé válnak: félelmet ébresztenek, ami a veszély hihetőségét és a vele szembeni fellépés jogosságát legitimálja. A nemzetközi vándorlás és a migráns népesség megítélésével és politikai kezelésével kapcsolatban fordulópontot jelentett a migráció gazdasági és kulturális kockázatként való megjelenése, illetve az erről a veszélyről szóló diskurzusok elterjedése. A befogadó országok többségében a biztonságosítás diskurzusa párhuzamosan épül fel előbb a multikulturalizmus, majd a menekültjogi rendszer válságának diskurzusával, ami erősíti azt az amúgy is meglévő tendenciát, amely a veszélyeket a gazdasági szférából a kulturális szférába és az identitás területére emeli át. ${ }^{4}$

A kulturális veszélyeztetettség diskurzusát az idegeneknek az európai nemzetekkel összeférhetetlen másokként való megjelenítése erősíti meg. Az új rasszizmus diskurzusa a biológiai különbségtétel

3 Buzan, Barry - de Wilde, Jaap - Wæver, Ole: Security: A New Framework for Analysis..., i. m., 1998.

${ }^{4}$ Huysman, Jef: The European Union and the Securitization of Migration..., i.m., 2000.; itt Szalai András - Göbl Gabriella: Securitizing Migration in Contemporary Hungary..., i. m., 2015.

REGIO 24. évf. (2016) 4. szám 5-32. 
helyett morális és kulturális okokra vezeti vissza a különbséget, amit előbb csak a politikai és a médiapaletta szélén elhelyezkedő, „szélsőséges” aktoroknál, majd mind inkább a fóáramban, végül a hétköznapi beszédben is azonosítottak Európa több országában. Azt a diskurzust, amely az idegenektől való félelemnek ad hangot, formáját tekintve xenofób, lényegét tekintve azonban a rasszizmus logikája határozza meg, a szakirodalom xeno-rasszizmusnak ${ }^{5}$ nevezi. A xeno-rasszizmus implicit formái jobban terjednek Európában, mint a neofasizmus explicit rasszizmusa, állapították meg a kérdés nyugat- és észak-európai kutatói. ${ }^{6}$ A félelem, aminek a xeno-raszszista diskurzusok hangot adnak, nem konkrét tárgyhoz kötött, többnyire nem nyilvánvaló, hogy kitől és miért kell félni. Az viszont számos vizsgálatból kiderül, hogy társadalmi szintü félelmek és elégedettlenségek állnak mögötte. Ezeknek többnyire társadalmi és gazdasági okai vannak, amelyek az idegenektől való félelem diskurzusába projektálódnak. Az Adornot és Horkheimer által is alkalmazott freudi érvelés a félelmek exteriorizálásának és az idegenek lealacsonyításának és kizárásának logikáját kapcsolja össze. ${ }^{7} \mathrm{Az}$ érzelmek manipulálásán tehát nagy hangsúly van, ami elsősorban a félelmek megnevezéséről, tárgyiasításáról, közvetve azonban a büszkeség és az önérzet helyreállításáról is szól. Diskurzuselemzők ${ }^{8}$ és a nacionalizmus új formáinak kutatói hangsúlyozzák, hogy a helyreállítást, a büszkeség és önérzet rehalibilitálását a nemzetek újravarázsosításával ${ }^{9}$ érik el, ami ugyanakkor együtt jár a nemzetek elképzelt tisztaságát és autenticitását sértő másságok kizárásával és leértékelésével. Vagyis a rasszizmus új formái összekapcsolódnak a nacionalizmus új formáival. ${ }^{10}$

A politikai propaganda kutatói már régen tudják, hogy háborút indítani és fenntartani elsősorban a tömegérzelmek manipulálásával lehet. Ennek legfontosabb eleme az ellenség víziójának megalkotása és ellenőrzése olyan diskurzusokkal, amelyek az idegent

\footnotetext{
${ }^{5}$ Fekete, Liz: The Emergence of Xeno-racism..., i. m., 2001.

${ }^{6}$ Essed 1991.

${ }^{7}$ Wodak, Ruth - Delanty, Gerard - Jones, Paul: Introduction..., i. m., 2008.

${ }^{8}$ Wodak, Ruth - KhosraviNik, Majid: Dynamics of Discourse and Politics..., i.m., 2013.

${ }^{9}$ Feischmidt Margit - Glózer Rita - Ilyés Zoltán - Kasznár Veronika Katalin Zakariás Ildikó: Nemzet a mindennapokban..., i. m., 2014.

${ }^{10}$ Feischmidt Margit - Hervik, Peter: Mainstreaming the Extreme..., i. m., 2015.
} 
ellenségként, méghozzá veszélyes és alacsonyabb rendü, ezért elpusztítható ellenségként jelenítik meg. A lealacsonyításnak két módja van: a rasszizmus, amely más fajhoz tartozónak, de még mindig emberi létezőnek tekinti az ellenséget, vagy a dehumanizáció, amely az ellenséget állatként azonosítja. A rasszizmus új formáiról az imént szóltunk. A dehumanizáció stratégiáját elsősorban olyan kutatók azonosítják és írják le, akik a biztonság védelmében és a terror ellenében meghirdetett háború (war on terror) politikai és médiadiskurzusát elemzik.

A szeptember 11-ei terrortámadást követően, a Bush kormányzat külpolitikai céljait legitimáló médiában, és nemcsak a szélsőséges nézeteikről ismert médiában, hanem a föáramban is, ilyen dehumanizációs diskurzus jött létre a muszlimok, mint a veszélyt megtestesítő ellenség megjelenítésére. ${ }^{11}$ A szerzők emlékeztetnek azonban arra is, hogy a muszlim emberekkel és népekkel kapcsolatban állat metaforákat használó beszédmód nem csak az amerikai, hanem az európai politikai beszédben is jelen van, Pia Kjorsgaards dán parlamenti képviselő például a muszlimokat Dánia rákbetegségének nevezte. ${ }^{12} \mathrm{~A}$ metaforikusan megidézett állatok egy része félelmetes, másik része undorító és szapora, de legfőképpen az jellemző rájuk, hogy alacsonyrendűek. Az állatokkal való összehasonlítás lényege azonban nemcsak a lefokozás, hanem a megsemmisítés legitimálása is. Az állatokkal azonosított ellenség elpusztítása nemcsak lehetséges, de egyenesen morálisan igazolható cselekedet. Ha az ellenség egy betegség, a megsemmisítése logikus és felelősségteljes válasz ,az” ember részéről.

A biztonság fogalmának a politikai diskurzusok középpontjába való beemelése nemcsak politikai értelemben hoz létre rendkívüli állapotot, hanem a társadalmi percepciók és beszédmódok szintjén is. A rendkívüli állapot Agamben szerint az emberek és a területek sajátos kategórizációjával és a hozzájuk kapcsolódó hatalmi technikákkal dolgozik. ${ }^{13}$ A rendkívüli állapotokhoz rendkívüli, „törvényen kívüli” területek tartoznak, például a táborok, ahová a társadalmat veszélyezteto „idegeneket” internálják. Didier Fassin arra hívja fel a figyelmet, hogy a határoknak kulcsszerepük van a biztonságosítás

\footnotetext{
${ }^{11}$ Steuter, Erin - Wills, Deborah: The vermin have struck again..., i. m., 2010.

${ }^{12}$ Uo: 2010: 55.

${ }^{13}$ Agamben, Giorgio: State of Exception..., i. m., 2005.
} 
révén történő kormányzásban, ami egyfelöl az államhatárok fokozott felügyelete által valósul meg, amihez fizikai akadályok, kerítések, falak, az erőszakszervek jelenléte, valamint a határsértőket fogva tartó táborok tartoznak; másfelöl olyan diskurzusok révén, amelyek egyre mélyebb és áthidalhatatlanabb társadalmi határokat jelölnek ki a népesség különböző csoportjai között. ${ }^{14}$

Az alábbiakban egy példán keresztül azt mutatom be, hogy a társadalmi határok kijelölése, az idegeneknek ellenségként való megjelölése és az országhatár biztonsági okokra hivatkozó megerősítése hogyan történik Magyarországon. Az elemzés középpontjában egy konkrét település áll, ahhoz azonban, hogy az érthető és megfelelően értelmezhető legyen, a tágabb kontextust vázolom fel előbb.

A biztonságosítás és a veszélyes idegen a kormányzati diskurzusban

A nemzetközi vándorlással összefüggő veszély és a biztonságosítás politikai diskurzusának felépítését Szalai és Göbl tárgyalják Magyarország esetében, azt állítva, hogy a biztonságosítás kormányzati diskurzusa jelentős mértékben nyugat-európai előzményeket követ. A biztonságosítás politikája Magyarországon a kormányfőnek az illiberális demokráciáról szóló beszédével kezdődött, amely a Nyugat válságának okát a multikulturalizmusban és túlságosan engedékeny migrációs politikában jelölte meg. ${ }^{15}$ Több elszórt kormányzati megnyilvánulás után a migrációról és a terrorizmusról szóló, ún. nemzeti konzultáció volt az első összehangolt akció. Az agambeni értelemben vett rendkívüli állapotra és a kollektív félelmekre apellálva ezt további akciók követték: a plakátkampány, a fizikai határzár, a kíméletlen bánásmód az országban feltorlódott menekültekkel. A Magyarországra bejutó menedékkérők száma a határzárnak tulajdoníthatóan jelentősen lecsökkent, ez azonban nem járt azzal, hogy az idegenrendészeti eljárás a kevesebb kérelmezővel szemben humánusabbá vált volna. Ellenkezőleg, néhány hónap alatt felszámolták az idegenek ellátására

\footnotetext{
${ }^{14}$ Fassin, Didier: Policing Borders..., i. m., 2011.

15 Szalai András - Göbl Gabriella: Securitizing Migration in Contemporary Hungary..., i. m., 2015.
} 
és állomásoztatására alkalmas majdnem teljes intézményrendszert. 2016 tavaszán pedig, nagyon kevés menekülttel az ország területén és egy aláírt uniós rendelkezéssel a hátunk mögött, amely a terhek megosztásáról szól, a kormányzat újabb kampányba kezdett. A kampány hatékonyságát jelzi, hogy az országban nőtt az idegengyülöletnek a szociológusok által mért szintje, ugyanakkor az ellenkező irányba mutató tendencia, hogy a népszavazáson való részvétel alatta maradt az érvényességi küszöbnek.

A kampány diskurzusára a biztonság, a veszély és az idegenek megjelenítése szempontjából most egyetlen dokumentum alapján tekintünk, amit a Kormány a 2016 októberében megrendezésre kerülő népszavazáshoz füzött magyarázatként. ${ }^{16} \mathrm{~A}$ kampány vezető szövege elsősorban Magyarország és az Európai Unió viszonyáról szól, a kvóta apropóján megfogalmazott szuverenitási nyilatkozat. A szuverenitási nyilatkozattal pedig egy erős állam imázsát igyekszik kelteni, amely technikai és politikai eszközökkel képes megvédeni az ország területét és polgárait. Lásd: A magyar kormány álláspontja szerint csak a magyarok dönthetik el, hogy kivel szeretnének együtt élni és kivel nem. Nem engedhetjük, hogy az ország jövöjét meghatározó döntések jogát kivegyék a magyar emberek és az Országgyülés kezéböl. Brüsszelt meg kell állítani! Itt válik explicitté a kampány címe - „Üzenet Brüsszelnek, hogy ők is megértsék” - és második legfontosabb funkciója (amely az elsővel természetesen szorosan összefügg), ti. erőt demonstrálni az Európai Unióval szemben.

A 2015-ös plakátkampány három témára építette a veszély képét: a közbiztonság, a kulturális identitás és a gazdasági jólét veszélyeztetésére, amit e diskurzus logikájának megfelelően a terrorista, idegen kultúrájú és segélyekből élő menekültek okoznak. A 2016-os népszavazási kampány ezt a képet kapcsolta össze az EU-val, amit a fent említett veszélyek fokozásával vádol. („Senki sem tudja megmondani, hogy hány terrorista érkezett a migránsok között eddig, és hányan érkeznek továbbra is nap mint nap. Márpedig terroristából egy is sok. [...] A más földrészekröl, más kultúrákból ideérkezö emberek tömeges betelepitése ennek megfelelöen veszélyt jelent a kultúránkra, életformánkra, szokásainkra és hagyományainkra. Ha

${ }^{16}$ Lásd itt: http://nepszavazas2016.kormany.hu/

REGIO 24. évf. (2016) 4. szám 5-32. 
nem cselekszünk, pár évtized múlva nem fogunk ráismerni Európára. [...] Az Európai Unió vezetői ráadásul úgy telepitenének be migránsokat, hogy a munkanélküliek aránya az európai fiatalok körében évek óta 20 százalék felett alakul. Egyes uniós országokban olyan súlyos a helyzet, hogy minden második fiatal állástalan. Álláspontunk szerint mindenekelött a már itt élö, munkanélküliséggel küzdö országok fiataljainak kellene munkát adni. Itthon vannak Európában, Brüsszelnek elsősorban velük kell szolidárisnak lennie.")

Összefoglalásként elmondhatjuk, hogy a nemzetközi migráció a kormányzati diskurzusban biztonságpolitikai és az ország szuverenitását érintő kérdésként merül fel. Humanitárius probléma a kormányzati diskurzusban nem, csak annak kritikájában, a hazai és nemzetközi emberjogi szervezetek és civil aktivisták, részben az ellenzéki pártok diskurzusában merül fel, ennek mélyebb vizsgálatára azonban itt nem vállalkozunk. Még kevésbé jelennek meg ebben a diskurzusban maguk a menekült vagy migráns emberek, róluk leginkább rendészeti problémaként esik szó, amely a határsértések vagy illegális határátlépések számaként tematizálódik. Ez a hallgatás azonban lehetővé tesz bizonyos hétköznapi diskurzusokat, amelyeket a következőkben röviden a déli határ közelében fekvő két településen végzett terepmunkánk tapasztalatai alapján fogunk jellemezni.

\section{Az idegenekkel való találkozás elbeszélése}

A kutatás fókuszában álló Csongrád megyei település közelmúltban városi címet kapott ugyan, a népesség száma és az infrastrukturális funkciók tekintetében azonban faluként müködik. A település Szeged vonzáskörzetében és a déli országhatár közelében található. A Homokhát egyik legnagyobb kiterjedésű szórt tanyás települése (közigazgatási területe 12.254 hektár, melyböl 12.088 hektár külterület). Állandó lakossága a 2012-es népszámlálás szerint 4019 fó, melynek közel fele (47,43\%) külterületen él, ahonnan a belterületen lévő infrastrukturális szolgáltatások nehezebben érhetők el. A külterületen élők száma fokozatosan emelkedik. Ennek legfontosabb oka a megyeszékhelyen élö vagy a környékén lakó és napi megélhetési gondokkal küzdő, általában sokgyermekes családok kiköltözése. A teleülést tehát már jóval a 2015-ös menekülthullám 
elött is mélyen érintett a migráció, elsősorban a szociális okokra visszavezethető belső vándorlás, másfelől a munkavállalási célú kivándorlás formájában. ${ }^{17}$

2015 nyarán a falu utcáin, a határban, a kertek alatt nagy csoportokban feltünő embereknek a hétköznapi életet megzavaró látványa kezdetben szánalmat ébresztett az ásotthalmiakban: „Amikor kevesebben jöttek, akkor sajnálta a nép, és segített, ahogy tudott. De ahogy a tömeg növekszik, meg ahogyan unják, egy idö után mind kevésbé és kevésbé kívánatosak". A kezdeti szánalmat azzal magyarázták, hogy „az első hullámban” - ezt a helyiek 2015 teléhez és tavaszához kötik - kevesen jöttek, sokan közülük jól öltözött, tanultnak látszó férfiak voltak, akik többnyire rejtőzködtek, alig látta öket a falu. A népi percepció által érzékelt második hullámban már elsősorban családok érkeztek, sok volt a nő és gyerek. A segítő szándék itt nyilvánult meg leginkább. Egy köztiszteletnek örvendő asszony a szánalom hangján beszélt nekünk az adott időszakra vonatkozóan: „Megálltam, mert a szíve szakad meg az embernek, amikor látja, hogy télben-fagyban, leroskadva a földre, ott ülnek ezek az emberek. Akkor beszéltük a kollegákkal, hogy lehet, hogy kéne nekik vinni teát, kitalálni, hogy s mint, hogy tenni kell valamit, mert ez egy rémület. Az orvosunk mesélte, hogy olyan csecsemöhöz hívták, aki gyakorlatilag félig meg volt fagyva. [...] Mondták azt is, hogy szellemi sérült embereket, öt másikat hoz egy valaki, mert azt a kvótát, amit remélnek, hogy kapnak, majd értük is megkapják és ilyenek. Látszott, hogy mindenkit visznek magukkal, akit lehetett.” 2015 nyarán, amikor már nagy tömegek érkeztek, a fiatal férfiak túlsúlyát érzékelték. Erre a korszakra vonatkozóan azonban az érzékelés és a beszédmód is megváltozik: „[...] amikor túlzásba vitték a jövetelt, amikor százával jöttek, ezek a suhernyák, ezek a 1314 évesek, bandákba verödve [...] csak az áradatot érzékeltük".

Ez az elmozdulás a percepciók szintjén természetesen nem csak a jelenség, hanem a keretezés változásával is összefügg. A média és a helyi politikai kommunikáció hatása felül tudta írni a hétköznapi percepciót. A korábban részben szánalomra méltónak, részben riasztónak gondolt emberek érzékeléséből az előbbi elem teljesen háttérbe szorult, az utóbbi vált meghatározóvá. Sem a politikai diskurzusokból, sem a médiából nem tudták kiolvasni az ásotthalmi

${ }^{17}$ Esélyegyenlöségi program..., i. m., 2008.

REGIO 24. évf. (2016) 4. szám 5-32. 
emberek azt, hogy rendben van, ha a melegben vizet adnak az úton levőknek, vagy ha pihenni hagyják őket az útszéli fák árnyékában. Az interakció delegitimálása, az ismeretlen idegenek veszélyként való azonosítása viszont annál inkább megtette a hatását. 2015 szeptemberében és októberében, közvetlenül azután, hogy a határzár megépült és a falu érintettsége megszünt, az ásotthalmiak már arról beszéltek, hogy személyes interakciók nem jöttek létre közöttük és a falun átvonuló menekültek között. Arra a kérdésemre, hogy „volt-e példa arra, hogy szóba álltak valakivel”, leggyakrabban azt a választ kaptam, hogy: „Én ilyenröl nem nagyon tudok, de lehet, hogy az ilyent nem is nagyon mondják el az emberek. Engem egyszer megszólított egy ember, de semmit sem értettem, tovább is mentem."

A személyes kapcsolatfelvételt az önkormányzat informális eszközökkel tiltotta: „El volt terjesztve a faluban, hogy nem szabad társalogni a menekültekkel”. A tiltásnak voltak azonban formális eszközei is, büntették azokat, akik segítettek. „De olyan is van, hogy egy tanárnö jött [...]. autóval és megsajnált egy asszonyt két gyerekekkel, felvette öket. A rendör ráfogta, hogy embercsempész, azóta sem zárult le a bíróságon az ügy. Ezt emberségböl tette, pénzt nem vett el. És a busz, amelyik elvitte? Az is embercsempész? Vagyis nem mindenki embercsempész, aki embercsempésznek van nyilvánítva." Az önzetlen segítők büntetése és stigmatizációja elérte a kívánt hatást. Mindeközben a csempészet továbbra is intenzíven zajlott. Terepmunkánk során magunk is láttuk a falu közelében levő gyüjtőponton, sőt a falu központjában is nagy számban várakozó autókat, meglepő módon azonban a gazdasági érdek sem tudta normalizálni az együttmüködést. Ha a témával kapcsolatban meg is nyílt egy-egy beszélő, csak odáig jutott el, hogy a „cigány csempészekről” beszélt, akik „megszabadítanak bennünket a migránsoktól”. A falusi közvélemény szerint más településekröl érkezett „cigányok” voltak az „állandók”, akik mellett „,helyi magyarok”, „csak beszálltak egy-egy körre”. Érdekes és figyelemre méltó, hogy a határ túlsó oldalán található szerbiai testvérfaluban a menekültek szállításáról, részben mint egy legitim dologról beszéltek, amely félig szolgáltatás, vagyis biznisz, félig önkéntes segítségnyújtás, és különböző bevett formái vannak, a munka utáni alkalmi szállítástól a taxiszerü müködésig.

Fontos azonban, hogy a faluban voltak olyanok, akik nemcsak a menekültek érkezésének első szakaszában, hanem mindvégig a több- 
ségtől eltérő módon viszonyultak hozzájuk. A helyi katolikus pap saját álláspontját ambivalensnek nevezte. Ezt a prédikációi is tükrözték, amit a vele folytatott beszélgetések során megerösített. Az ambivalencia lényege, hogy a szívre vagy az észre hallgatva, keresztény emberként vagy politikusként másként ítéli meg az ember a Magyarországot is elért nemzetközi vándorlást: „Ha a szívünkre hallgatunk: akkor azt kell mondanunk, emberekröl van szó [...] Amíg mi jóléti államokba pazarolunk, addig más országokban éheznek. Érthetö, ha nem tudnak fegyverrel elfoglalni bennünket, elfoglalnak fegyver nélkül. [...] Sokgyermekes szerencsétlen családok, legalább mi forduljunk feléjük szeretettel. A másik emberben Jézust látjuk, aki velünk emberekkel azonosítja magát, segítenünk kell, mert egymásra bízott az Isten [...] „A magyar kormánynak (viszont) kötelessége megvédeni a nemzetünket."

A dilemmát úgy oldotta föl a maga számára, hogy személyesen és papként segített a faluban megjelenő és hozzá forduló menekülökön. A plébánia egy ideig nyitva állt előttük, és több család, illetve kisebb csoport számára szolgált átmeneti szálláshelyként. Vendégeinek egy része keresztény volt, és még olyan is volt közöttük, mesélte a pap, aki arab nyelvü Bibliát hordozott magával a hátizsákjában. Amikor látták, hogy a volt ferences szerzetes könyvespolcán különböző nyelvü bibliák sorakoznak, neki akarták ajándékozni, amit viszont ő utasított el arra való hivatkozással, hogy a hosszú úton és a menekülteljárás során még szükségük lehet rá. A papnak legfeljebb két, Szegedről ingázó föiskolás ministráns segített a menekültek körüli munkában. A helyiek, akik ugyan „templomba járó és konzervatív” emberekként jellemezték magukat, sem a menekültek körüli munkában, sem általában a plébánia müködtetésében nem aktívak. Ezek az okok biztosan közrejátszanak abban, hogy ha az irgalmasság példája meg is jelent a faluban, nem terjedt el, távolról sem vált tipikus viselkedési formává.

A személyes kapcsolatfelvételnek voltak azonban más elszigetelt példái is. Találkoztunk például olyan ifjú polgárőrrel, aki szerint a polgárörök feladata általában az, hogy a falut „védjék”, ebben az esetben, hogy a menekülteket „eltereljék”. A polgáröröket többnyire a helyi közösség elismerése motiválja, interjúalanyunkat azonban az idegenek iránti kíváncsiság is hajtotta. „A világ vonult át a falun” fogalmazott. Míg örizte az elfogott határsértőket, beszélgetett velük. Ennek köszönhetően, mondta, „ma sokkal jobban eltájékozódik a 
világpolitikában”; három éve polgárőr, azóta megtanult angolul, és részben szerbül is. A család kertjén rendszeresen átjártak a menekülő idegenek, de több kárt, mint hogy néhány barackot leszedtek, nem okoztak. Nem féltek tőlük, sőt sajnálták őket, amit nélkülözni tudtak, önként nekik adták. Az ifjú polgárőr és családja az idegenekkel való „emberi” viszonyt hangsúlyozta, a hétköznapi találkozások természetességét: „Volt, akivel összehaverkodtam úgymond, ...elbeszélgettünk, normális volt. Elmondta, hogy mit szeretne, ki szeretne menni Németországba, dolgozni akar majd. Volt olyan hogy a koszovóiakkal a foci vb-t is kitárgyaltuk, tehát az ilyen kétoldalú." Ebből a perspektívából az érzelmileg pozitívan ható, megrendítő történetek váltak elbeszélésre érdemessé, pontosan úgy, mint a pap esetében a Bibliával a hátizsákban menekülő szíriai családé.

\section{A félelem és a deviancia megjelenése a hétköznapi diskurzusokban}

A folyamat elején feltünt beszédmódbeli diverzitás egyszer csak eltünt. Az elbeszélések egyre nagyobb fokú homogenitást mutattak. A mocsokról, a higiéniás veszélyről és az elkövetett károkról szóló diszkurzív kereteket töltötték fel erősen szelektált megfigyelésekkel: „Volt, akinek a villanypásztorát széttépték, a marhái meg szétmentek, aztán két-három napig hajkurászta őket, azt a hetven-nyolcvan marhát... Meg a barackosok... Emellett a rengeteg szemét, amit elhagytak maguk után. Óriási probléma, nem beszélve a fertözésveszélyröl, pelenkák eldobálva az út szélén. Tanyán él a lakosság negyven-ötven százaléka, és nem mernek kimenni az udvarra. Éjszaka bekopogtatnak hozzájuk. A biztonságérzetet... Ásotthalom egy biztonságos település volt, az most is, függetlenül ettöl, most ezen a migrációs hullámon túl vagyunk, de lesz még. Ezek az emberek nem állnak meg."

A faluban nem nőtt meg a kihelyezett hulladékgyüjtők száma. Ezért az a beszéd, hogy sok helyen eldobott flakonok, élelmiszercsomagolóanyagok és ételmaradékok, pelenkák, sőt a szántóföldeken emberi ürülék volt látható, rendelkezett valóságalappal. De amíg néhányan ennek az érthető voltát hangsúlyozták, a falubeli emberek többsége a veszélyek és a deviáns viselkedés igazolását, és a menekült emberek lényegét alkotó vonásokat ismertek fel a szemetelésben. Miután a kommunikáció és a személyes interakció 
egyre ritkábbá vált, az idegenek egyre inkább biológiai, testi létezésükre korlátozottan jelentek meg az elbeszélésekben. A hozzájuk való viszony megjelenítésében pedig olyan érzelmek kerekedtek felül, mint az undor, a méreg, a bosszúság. A rájuk jellemző cselekvések megnevezésére olyan igéket használtak, amelyeket máskor az állatok csoportos mozgásának megnevezésére szoktak, például mindent „elleptek”, a buszokat, a mentőt, a mindennapi rutinokban megakasztották a helyieket.

Az önkormányzattól megtudtuk, hogy Ásotthalmon 2016 őszén a korábbi hónapokra vonatkozóan hat magántulajdon elleni sérelmi esetet vettek nyilvántartásba, a bejelentett összes kár pedig 1,6 millió forint volt. Még ez sem nyert akkor bizonyítást, de a társadalmi érzékelés mindenesetre sokkal jelentősebb veszteségekről szólt. Az elbeszélések azonban nem csak a konkrét tapasztalatokra épültek, hanem egy fokozódó általános félelemből is táplálkoztak. Az ismeretlentől való félelmet a médiából származó információk nem eloszlatták, hanem tovább fokozták: „Folyamatosan beszélnek és ott az aggodalom, hogy elment a rengeteg férfi, ezután majd egyszer csak elindul a családja. És mennyi ember lesz ebböl? Mert mostan itten nem tudom hány ezer elment, meg nem tudom, hány ezer kint van szerintem senki sem tudja pontosan, hogy mennyi van, csak egy hozzávetöleges adat. Na de ehhez hozzá lehet csatolni egy jelentös mennyiségü embert még. Meg hát azt is el kell mondjam, hogy nem is olyan túl régen, amikor volt Röszkén ez a cirkusz ott a határnál, elötte héten volt az, mikor jött egy férfi - volt vagy 9-10 gyerek, volt 3 asszony, meg egymaga. Na, mostan ez így jött már, de ki tudja, hogy hány olyan férfi jött, akinek több asszonya van, és majd hány gyerek fog utána jönni. Tulajdonképpen ezek a dolgok azért benne vannak a levegöben, erröl beszélnek itt a faluban. Ezek az aggályok abszolút bennünk vannak. Meg az, hogy ki fogja ezeket etetni, meg honnan lesz erre pénz, meg az, hogy azt halljuk, hogy ök úgy jönnek, hogy Németországban meg az osztrákoknál borzasztó jó a helyzet. És hogyha nem kapja meg azt, amit vár, akkor abból mi lesz? - ez az egyik, becsapottá válik. Másik az, hogy, amit hallunk a TV-ben, hogy mennyit vissza fognak küldeni."

A félelem által táplált ellenérzéseket az irigység és a gyanakvás fokozta. Hogy jönnek a mások segítségére számító emberek ahhoz, hogy drága okos telefonokkal, ruhákkal, cipőkben szaladgáljanak a világban? Akinek ilyen telefonja van, az nem szegény, és, ha úgy 
tesz, akkor hazudik. A fokozódó düh és gyülölet fizikai formát sohasem öltött, a menekülő emberek a falubelieket nem bántalmazták, az agresszió nyelvi formában azonban annál gyakrabban fogalmazódott meg: „Ennyi fiatalember... ezek, ki tudja, fegyerforgatásban meg késforgatásban otthon vannak... félünk, na félünk. Most beengedik iskolába ezeket a magyar gyerekek közé mit visznek azok oda be... Én ettöl félek, vagy attól, hogy megyek az utcán és akkor, ha nem tetszik nekik a pofám, akkor nekem jönnek, vagy ha valaki autót vezet, itt van az az eset, amikor a cigány gyereket fellökte....Olaszliszka. Volt már azóta máshol is.”A hétköznapi gyülöletbeszédről elsősorban olyanok tudósítottak, akik nem azonosultak vele. Ugyanakkor azt is érzékeltették, hogy nem volt kapaszkodójuk vele szemben, vagyis ellendiskurzus nem alakult ki: „Volt, aki húsz méterröl ordibálta, hogy miért nem dobtok rájuk bombát, meg hogy miért nem lövitek le.” „Vannak itt olyan emberek, akiknek jó, köszönök, de amikor meglátja a migránsokat, akkor köpköd, az utálatát fejezi ki, hogy 'na ezek a rohadékok'."

A határ menti faluban megjelent idegenekről a hétköznapi életben kialakult diskurzust a veszély és a deviancia képzete uralta, amit a percepció érzelmi irányítottsága és a külső aktorok reprezentációi határoztak meg. Ez elsősorban azt jelentette, hogy a diskurzusból kizárták a közvetlen társadalmi tapasztalatokat. Kizárták a saját migrációs élményeket, beleértve a helyi emberek vendégmunkástapasztalatait és a faluban élő külföldiekkel kapcsolatos élményeket, kizárták a meneküléssel kapcsolatos korábbi emlékeket, amelyek a határ közelsége miatt a délszláv háborúhoz, 1956-hoz vagy a háborúkat követő határmódosításokhoz kötődnek, és az eltérő kultúrájú emberekkel való találkozás hétköznapi tapasztalatait, amelyek a határ közelsége miatt ugyancsak gyakoriak az itt élök életében. (A falu lakói például rendszeresen látogatják a határ túlsó oldalán levő települések piacait.) Amiként a határ szerb oldalán élők elbeszélései rávilágítanak, a személyes találkozások, és a menekülés különböző korokból és az ezen helyzetekből származó látvány, a határközeliség tapasztalatai mind a megértés és az együttérzés irányába mutatnak. Ezek kizárása a közbeszédből kiszolgáltatottá teszi az embereket a politikai és média aktorok által irányított nyilvános diskurzusoknak, amelyeket a következő fejezetben fogunk röviden bemutatni. 
A veszély és a védelem diskurzusának felépítése a helyi politikában és a médiában

Több forrás állítja, hogy a határzár építésének gondolatát az ásotthalmi polgármester vetette fel. Ezt a vele készített interjúban számunkra is megerősítette: „A magyar kormány most nagyon helyesen cselekszik. Azt gondolom egyébként, egy történelmi tettet hajt végre, mert ez itt egy globális probléma. Amit most tesz a kormány, az tökéletes, amit tesz. Tehát le kell zárni a schengeni határokat. A schengeni határokat védeni kell. A határok azért vannak, hogy ott be kell tartani a törvényeket, azt nem lehet agresszívan áttörni. Ami most történt, ez egy agresszió, az egy támadás. Csak addig nem voltak agresszívek, ameddig nem mondtuk azt, hogy emberek, ez törvénytelen, ezt nem csinálhatjátok. Azonnal agresszívvé váltak. Az nem csoda, hogy nem agresszívak, amikor kenyérrel, vízzel fogadjuk a törvénysértőt és ingyen elbuszoztatjuk az osztrák határhoz, tehát ne csodálkozzunk rajta. Abban a pillanatban, hogy a szlovén rendör megállította, már nekitámadt a szlovén rendörnek. Röszkén láttuk, hogy milyen támadás érte a hatóságokat. Ez egy agresszió, törvénytelen agresszió."

A határzárat a kormány hozta létre. A felügyeletnek egy másik része azonban önkormányzati jogkörben valósult meg, a polgárörség és a polgármester által létrehozott mezőőrség bevonásával, ami nemcsak a helyi lakosság, hanem a távol élő szimpatizánsok támogatását is élvezte. A polgármester így számolt be erről a tevékenységről: „Ha jól tudom, elsőként az országban én alapitottam meg Ásotthalmon a Mezöörséget 3 fövel. Emellett egy 18 fös polgárörségünk van, amit azt gondolom, hogy elödömhöz képest sokkal jobban támogatom - mind anyagilag, mind erkölcsileg. (...) Kezdetben egy öreg orosz Lada Nivával, idönként lovakkal jártak, aztán ahogy eszkalálódott a helyzet, kértem a Belügyminisztériumtól egy új terepjárót. Azt ugye nem kaptunk - ennek formai okai voltak. (...) Annyira sürgetö volt, hogy feltettem a Facebook-oldalamra a felhívást, hogy gyüjtünk egy terepjáróra. 1 hónap alatt összegyült 5 és fél millió forint, abból vettünk egy Toyota terepjárót. Ezzel a Toyota terepjáróval erösitettem meg a Mezöörséget. Most ott tartunk, hogy felemeltem háromról 5 före a Mezőőrség létszámát. (...) És ezért az 5 mezöör mellé, ök ugye 24 órás szolgálatot látnak el, még 24 órában van egy biztonsági ör. És így tulajdonképpen 6 fövel dolgozunk. Ök

REGIO 24. évf. (2016) 4. szám 5-32. 
azok, akik ugye az önkormányzattal szerzödéses, vagy munkaviszonyban álló hivatalos személyek.”

Egy falugyülésen, amelyen a helyiek többsége részt vett, a polgármester a közegészségügyi veszélyekre hívta fel a figyelmet. Az illetékes hatóság jelen lévő képviselője hiába igyekezett csökkenteni a pánikot azzal, hogy hangsúlyozta, nincsenek aggodalomra okot adó konkrét esetek, a faluban számos helyen megjelentek azok a plakátok, amelyek egy leprás beteg kezét és egy egészségügyi intervenciót ábrázolnak. Egész nyár folyamán arra figyelmeztették az embereket, hogy minden érintkezést a személyekkel és hátrahagyott tárgyaikkal, kerülniük kell.

A falu lakóinak nagy része egymástól viszonylag távol eső tanyákon él. A polgármester elsősorban az ő félelmeikre építette a kommunikációját. A biztonságérzet általános megromlásával „a települést megöli ez az illegális migráció”, magyarázta a mozgósítás szükségszerüségét, a védelem megszervezését. A katonai egyenruhában járőröző mezőőrök és polgárőrök láthatóságát a közösségi médián forgalmazott videóval fokozta. A videót, amely hollywoodi filmekre emlékeztető koreográfiában, illetve zene mellett mutatja be a hajtóvadászatra alkalmas eszközöket és férfiakat, így jellemezte a polgármester: „A videóüzenetben annyi van, hogy szeptember 15-töl Magyarország védi a határait, törvénytelenül nem lehet belépni, a kijelölt határátkelöhelyen útlevéllel, dokumentummal lehet belépni, azokat várjuk szeretettel. De aki törvénytelenül jön, az könnyen börtönbe kerülhet ugye az új magyar jogszabályi szigorítás miatt, és Ásotthalmon egy nagyon militáns mezöörség és polgárörség segiti a több ezer rendört és katonát. Ezt bemutatjuk képileg, a katonák hogy dolgoznak, jönnek motorral a videón, terepjáróval, lóháton a mezőőreink, tehát egy ilyen elég katonás kis videó. Ezért lett valószinüleg ilyen népszerü, aminek ez az üzenete, hogy védjük a határt, nem érdemes Ásotthalomnál próbálkozni. És ami most ilyen szállóigévé vált a világban ez a két utolsó mondatom, amivel befejezödik ez a 2,5 perces videó: 'Ha Ön illegális migráns, ne higgyen az embercsempészeknek, Magyarország rossz választás, Ásotthalom pedig a legrosszabb.",

A filmben a mezőőrök és polgárörök autóval, motoron és lóháton pásztázzák a déli országhatárt, amit részben madártávlatból, részben testközelből lát a néző. A falu és annak lakói nem láthatók, csupán távoli díszletei annak a performansznak, ami az erőt hivatott 
demonstrálni, amivel a Magyarország határához érkező menekülteknek szembe kell nézniük. A rövid és dinamikus, népszerü formákat alkalmazó, a Youtube-on megtekinthető film valóban nagyon gyorsan terjedt el. A magyarországi szélsőjobboldal vezető információs forrása, az Alfahír már másnap azt írta: „szerte Európából köszönetet mondanak Torockainak" ${ }^{18}$. Az első napi letöltések száma 150 ezer volt, ami rövid időn belül sokszorosára gyarapodott, a polgármester a vele készült szeptemberi interjúban 1,5 millió letöltést említett.

A film, ami „anti-refugee movie” címen járta be a világot, nemzetközi pályafutását pozitív és negatív reakciók egyaránt kísérték, amelyek együttes hatása, hogy Toroczkai a menekültekkel szembeni fellépés médiasztárja lett. A Russia Today a háborúk és éhezés elleni fellépést emelte ki a filmből, amit Torockai korábbi szélsőjobboldali radikalizmusával hozott összefüggésbe. ${ }^{19}$ Az orosz média másik része különösen pozitív fogadtatásban részesítette, a militáns fellépés mögötti „munkás hétköznapokkal” legitimálva a polgármestertől a cikk címében idézett állítást: „Minden illegális migránst az USA-ba küldenék." ${ }^{20}$ Ugyanaz az újság néhány hónappal később lelkesen számolt be arról, hogy Ásotthalmon emlékmüvet állítottak és utcát nevezte el Gagarinról, amely eseményen Oroszország budapesti konzulja is részt vett.

A Brexittel összefüggésben korábbinál is nagyobb hírnévre szert tett brit tablóid, a Daily Mail online változata különösen részletesen foglalkozott a film és vele összefüggésben a magyar- szerb határon 2015. szeptember elején kialakult válságos helyzet leírásával. A cikk visszafogott hangneme ellenére alkalmat teremtett és terepet kínált arra, hogy a brit jobboldali radikális olvasók Toroczkaival kapcso-

\footnotetext{
${ }^{18}$ Lásd http://alfahir.hu/szerte_europabol_koszonetet_mondanak_toroczkainak ${ }^{19}$ „In the two-minute-long action-packed footage Toroczkai, once expelled from a far-right party for being too radical, filmed alongside a dozen other tough guys, make it extremely clear that people running from war and hunger are not welcomed in their area." - (REF)

20 ”,I would send all illegal migrants to US - Hungarian Town Mayor http://sputniknews.com/europe/20151012/1028404649/asotthalom-mayorinterview.html\#ixzz471oqyFLu
} 
latos elismerő kommentjeiket nyilvánosságra hozzák. Azok a világhálón ma is elérhetők. ${ }^{21}$

Komoly médiaelemzők szerint Toroczkai álláspontja és a menekültellenes kisfilm a legszélsőségesebb európai álláspontot jeleníti meg. „Has Europe reached the Breaking Point” a címe a New York Times-ban megjelent cikknek, amely a menekültválság fényében elemzi az Európai Unió aktuális helyzetét, a hangsúlyt a bizonytalanságra helyezve. A cikkben a kerítés a szorongó Európa szimbólumaként jelenik meg. Toroczkait pedig, akinek a Magyarországot az Unióból kizáró kerítéssel és a menekültellenességgel teljesedik ki a politikai karrierje (, a rising ultranationalist star of farright European politics”), részben drámainak, részben abszurdnak mutatja be. $^{22}$

Toroczkai reputációja legnagyobbat minden bizonnyal azzal ugrott, hogy egy népszerü amerikai politikai kommentátor müsorába is bekerült. A Last Week Tonight with John Oliver 2015. szeptember 28-án az európai menekültekkel és migránsokkal foglalkozott ${ }^{23}$. 2016 augusztusában a nézettsége 8.477.532-en állt. A műsor felvezetője szerint azt mutatja be, hogy a migránsok, akik menedéket keresnek Európában, hogyan kénytelenek a gyülölettel és a rasszizmussal szembesülni. Toroczkai itt úgy jelenik meg, mint ennek a gyülöletgyárnak az egyik jelentős aktora. Van ebben talán némi túlzás, ami pont a média torzító, itt nagyító hatásával magyarázható. A megközelítés, amelybe John Oliver nemzetközileg (beleértve Magyarországot) nagy nézettségnek örvendő müsorában az esetet állítja, abszurddá, sőt nevetségessé teszi az ásotthalmi polgámestert. Pontosabban fogalmazva John Oliver felszabadítja a kisfilmben jelenlévő potenciált, ami a nézőket nevetésre ösztönzi.

\footnotetext{
21 http://www.dailymail.co.uk/news/article-3240272/Hungarian-mayor-mockedaction-movie-video-warning-migrants-not-enter-town-including-choreographedchase-horseback.html

22 „The fence had sealed Hungary off, and that made Laszlo Toroczkai — the 37year-old mayor of Asotthalom, a Hungarian farming town on the Serbian border, and a rising ultranationalist star of far-right European politics — very happy.”) http://www.nytimes.com/2015/12/20/magazine/has-europe-reached-the-

breaking-point.html?_r=0

23 Aa müsor címe Migrants and Refugees (HBO), s letölthetö innen https://www.youtube.com/watch?v=umqvYhb3wf4
}

REGIO 24. évf. (2016) 4. szám 5-32. 
Az ásotthalmi vonatkozású politikai kommunikáció harmadik fontos pillére a közösségi média, ahol a polgármester saját Facebook-közösségével kommunikál. A polgármester élénk közösségi média-kommunikációját az általa szinte napi gyakorisággal feltett posztok tartják mozgásban (követőinek száma itt meghaladja a 40 ezret). A közösségi médiának a faluhoz és a polgármesterhez kötődő részében a „migránsok” a leggyakoribb, szinte folyamatosan megjelenő szereplői, amiről részben önmagában, részben más témákhoz kapcsolódva van szó. Ilyenek voltak az elemzett hónapok során a polgármester és a Jobbik Magyarországért Mozgalom viszonya, a tanyákon élő rászoruló embereknek nyújtott segítség, a történelmi emlékezet (Rózsa Sándor, Szent Korona és Kapisztrán Szent János), külkapcsolatok (orosz prioritás, EU-kritika), és végül a polgármester magánélete (gyerekei, vallásossága).

Az alábbiakban az egyik ilyen „migráns” témájú posztját idézzük: „Az elmúlt napokban kétszer is arra ébredtem fel az éjszaka közepén, hogy a tanyánk keritésénél üvöltöznek a határsértök. A képeken az e heti fogásunk látható. A mezööreink egyre többször jelentik, hogy éjjel a kerítés túloldalán álló migránsok késekkel mutogatják a kerítést örzö mezööröknek, katonáknak, rendöröknek, hogyan akarják levágni a fejüket. Aztán, ha nincs ott éppen őr, máris vágják át a kerítést és rohannak az ország belseje felé. Most azonban mi is sokan vagyunk itt, általában néhány száz méter után elfogjuk, megkötözzük öket. A gond az, hogy ezzel azt elérjük, hogy nem tudnak ellenörizetlenül betörni Magyarország és az EU területére, ám az elmebeteg jogszabályok miatt - ujjlenyomatvétel, kitiltás után néhány nap után újra szabadon távozhatnak. Ez a törvényhozók felelössége. Messze nem oldódott meg tehát még ez a világunkat fenyegetö probléma. (FB, 2016.04.24.)

A drámai potenciállal rendelkezö, egyszerü történet hitelesítéséhez fénykép is tartozik, amely kutyájával ábrázolja a polgármestert, a háttérben pedig a győztes pozícióban álló polgárőr és a fogságba ejtett fiatal férfiak láthatók. A bejegyzést követő kommentek egy része a kutyáról szól, dicsérik a szépsége miatt, amit már a korábbi képeken való feltünései alkalmával is megtettek. A kutya állapotáról az etetésére terelődik a szó, a tápról a menekültekre, majd vissza, mert „csak minőségi táppal” etetik. A kommentek többsége a kutya és a polgárőr fogságában levő menekültek között teremt kapcsolatot. Az összes esetben a kutya javára, és több esetben 
azt mondva vagy sejtetve, hogy a menekült embereket a kutyával kellene feletetni („Mi lesz ezekkel? Blöki nem éhes?”) A kommentelők között nincsen vita, egyetlen dinamika érvényesül a kommunikációjukban, egymásra licitálva gyalázzák a menekülteket és ugyancsak egymást erősítve dicsérik a polgármestert. A nyelvi performansz csúcspontja az az elöbbiek megsemmisítése, amit a többek like-ja vagy smile-ja követ érzékeltetve, hogy senki sem veszi a résztvevők közül morális értelemben komolyan, ami elhangzik. („Igazából szélmalom harc, mert amit összefogdostok, pár óra/nap után megint szabadon kóricálnak szanaszét. Boom a fejbe.... smile hangulatjel Ui.: Szép a kutyus!” S következik a smile hangulatjel (9). A kommentek az eredeti felvetést támogató, erősítő, fokozó állítások, amelyek megfogalmazásában bizonyos stiláris és performatív elemek fontosabbak, mint az állítás igazság- vagy valóságtartalma. A verbális erőszak élét humorral veszik el, ami a gyülölet és a cinizmus sajátos egyvelegét valósítja meg.

A közösségi médiában folyó kommunikáció másik fő témája a politikai ellenség, a hazai és nemzetközi emberjogi és menekültsegítő szervezetek (amelyek ellen feljelentéseket is tett a polgármester, majd a perek lefolyásáról állandóan tájékoztat), az Európai Unió meghatározó politikusai, akikkel szemben nemzeti és nemzetközi összefogást hirdet. „Megérkezett az igazi terror Európába, ahogy azt elöre jeleztem, de csak kevesen vettek komolyan. Minden felelösség azoké a most sopánkodó és szörnyülködö politikusoké, akik rákényszerítették és még most is rákényszerítik a multikulturalizmust Európára. Ez csak a kezdet, ennél sokkal kegyetlenebb és kiterjedtebb terror vár az Európai Unióra (is). A megoldás pofonegyszerü: 1. Elzavarni a pokolba Merkelt, Junkert, Hollande-t és az összes többi sírásó politikai vezetöt. 2. Katonai erövel, dupla soros, brutálisan erös kerítéssel, vizesárokkal, tengeri hadiflottával lezárni az EU külső határait és minden ellenszegülővel szemben tüzparancsot adni. 3. A több millió, már bent lévö illegális bevándorlót egyenként átvilágítani, s aki nem ide való, azt azonnal kitoloncolni. 4. Ha mindez már müködik, akkor lehet elgondolkodni azon, hogy Európán kivül keresztényi szeretetböl kinek és hogyan segitsünk. De 
semmiképpen nem úgy, ahogy az eddig történt."24 (FB, 2015. nov. 15.)

Ásotthalomra, ahhoz hasonlatosan, ahogyan az előttük járó antropológusok és szociológusok más településekre, mi is mint labóratóriumra tekintettünk. Ezt a laboratóriumot nem mi hoztuk létre, hanem különböző politikai és társadalmi folyamatok együtthatásai, amelyek azt eredményezik, hogy máshol elszórtan ható tendenciákat itt koncentráltan lehet megfigyelni. A tanulmány első, leíró részének kiindulópontja azok a hétköznapi diskurzusok voltak, amelyekkel a menekültekkel való találkozás elbeszéléseit kereső kutató a településen talált. A vizsgálat rámutatott, hogy a személyes találkozások és a korábbi emlékekkel való asszociáció teljességgel hiányzik a hétköznapi diskurzusokból, vagyis a menekültekkel való találkozás a hétköznapi racionalitástól és személyes világoktól el lett idegenítve, a kollektív érzelmekre fókuszál, amelyeket hatalommal bíró aktorok, a politika és a média irányít.

A tanulmány következő fejezetében éppen ezért a média és a politika diskurzusait igyekeztünk leírni, rámutatva arra, hogy a lokális politikai gyakorlat hogyan függ össze annak távolról sem lokális céljaival és tétjeivel, továbbá a médiával, beleértve az ügyben nagyon fontos szerepet játszó közösségi médiát is. Bemutattuk, hogy a politika helyi szinten miként működik, ha az az idegenek kizárására és ellenségként való megjelenítésére és kontrolljára fókuszál; továbbá ezzel összefüggésben azt, hogy az idegenellenesség retorikájának megteremtésében milyen együttmüködés jött létre a politika és a média között.

Rámutattunk arra, hogy hétköznapi xeno-rasszista diskurzusnak milyen elözményei vannak a politikában, és milyen változatai jelennek meg a média, illetve a közbeszéd különböző szintjein. A magát a biztonság helyreállítójának szerepében megjelenítő polgármester láthatóan uralja az idegeneknek ellenségként való megjelenítését, amivel egyfelől saját politikai befolyását növeli, másfelől megteremt egy nyilvánosságot, amelyben létrejönnek és rutinizálódnak a dehumanizáció nyelvi, performatív aktusai. A két fejezet együttesen azt mutatja, hogy az idegenek minden esetben ellenségként jelennek meg, akiknek a reprezentációja a deviancia

\footnotetext{
${ }^{24}$ https://www.youtube.com/watch?v=WL7K_Qn_Z-E A fenti szöveg elhangzott Varsóban a lengyel szélsőjobbal által szervezett Nemzeti Függetlenség Ünnepen.
}

REGIO 24. évf. (2016) 4. szám 5-32. 
kulturalizálásától a lefokozás rasszizálásán át az állati metaforákkal való megjelenítésig terjed. Közöttük a legfontosabb különbség, hogy míg az első csak az elutasítást, a második a megvetést, a harmadik a megsemmisítést legitimálja.

A hasonlóságok alapján és a bevezetőben bemutatott elméleti előzményekre támaszkodva állítjuk, hogy a faluban dominánssá vált diskurzust a xeno-rasszizmus jellemzi. Az ásotthalmi xeno-rasszizmus hegemóniáját két körülmény teszi lehetővé: a helyi politikai diskurzus, amit megerősít a vele sok ponton egybecsengő kormányzati retorika, és nem tud gyengíteni a hazai és nemzetközi médiában megjelenő kritika. A másik körülmény a diskurzus történeti, kulturális beágyazottsága: a magyar nemzeti önképben benne rejlö orientalista szemlélet (muszlimok, törökök ellenségként való ábrázolása); a hiányzó globális szemlélet, a kulturális másság jelentésnélkülisége és hiánya a társadalom nagy részének mentális térképéről, valamint és leginkább a másság legfontosabb formájának (romák, cigányok) rasszizálása, amely az elmúlt évek egyik legjelentősebb folyamata Magyarországon. Számos idézett interjú és a közösségi médiában megjelent kommentek is azt mutatják, hogy a másság leértékelésének az a folyamata, amely a romák vonatkozásában elkezdődött - és a „cigánybünözés” fogalmának megteremtésében csúcsosodott ki - a menekültek viszonylatában tovább radikalizálódott, ami leginkább a dehumanizáló metaforákban öltött testet.

\section{Magyarázatok és következtetések: a xeno-rasszista diskurzus társadalmi háttere}

A falura mai önképe és a korábbi évtizedekben mutatott választói magatartás alapján egyaránt a konzervatív értékrend jellemző. A rendszerváltás utáni első ciklust leszámítva, amikor egy helyi kötődésű, de Szegeden élő jogász az SZDSZ támogatásával lett polgármester, a Fidesz dominálja az önkormányzatot és a térség parlamenti képviseletét egyaránt. De amíg a szomszéd település ezzel a kapcsolattal igen eredményesen sáfárkodott, és állami támogatások és piaci szereplők odavonzásával egy virágzó város benyomását keltő regionális központot hozott létre, a mi településünk jelentősége egyre csökkent. Ezen némiképp a kishatárátkelő megnyílása, az átmenő forgalom megélénkülése változtatott. A 2010-ban 
újraválasztott polgámester második ciklusában a testületet megosztó ellentétek és a polgármester morális válsága a közélet fokozatos szétesését eredményezte. A polgármester lemondása után 2013-ban hatalmi vákuum keletkezett. A Fidesz elveszítette helyi bázisát, és a szomszédban levő Fidesz-fellegvár mellett nem is volt érdekelt annak gyors helyreállításában. A baloldal fokozatos gyengülése kulminál, aminek nem helyi okai vannak, de helyben nem sikerül (mondjuk Szegedhez hasonlóan) átbillenteni a baloldal országosan jellemző válságát. A baloldal egy helyi vezetője, aki maga is a szélsőjobboldal jelöltjét támogatta az önkormányzati választáson, ezt a kudarcot igy fogalmazta meg: „Én baloldaliként szégyellem, hogy ennek a baloldalnak vagyok még a híve. Ez egy tragédia."

2013-ban robbant be a közéletbe a jelenlegi polgármester, a településhez személyes szálakkal kötődő fiatal férfi, akit korábban elsősorban a szélsőjobboldali szcéna követői ismertek. Az országos és fóáramú médiából néhány jelentősebb akciója vált ismertté, ilyen volt 2006 őszén a MTV székház elleni támadásban való részvétele, néhány évvel később az IMF magyarországi irodájának otthont adó Bank Center elleni támadás, revizionista tevékenysége miatt a környező országokból való kitiltása. A radikális jobboldal egyik vezéralakját tiszteli benne, akit egy ideig Budaházi Györggyel együtt emlegettek, több szervezetnek (például Hatvannégy Vármegye Ifjúsági Mozgalom, Betyársereg) és eseménynek (Magyar Sziget, a nemzeti rock zene fesztiválja, július 4-i Trianon-megemlékezések és felvonulások, támadás a melegek felvonulása ellen stb.) volt kezdeményezője és vezetője. 2013-ban időközi választásokon elért eredményét egy évvel később a rendes önkormányzati választásokon megerősítette. A Fidesz szavazóbázisa a helyi politikában mögé állt, míg az országos politikát illetően maradtak a Fidesznél, a miniszterelnök tekintélye, úgy tünik, nem csorbul. A politikai nézetek radikalizálódása csak az aktiv fiatalok és középkorúak esetében figyelhető meg. Az idősebbek inkább elnézik a polgármester radikális múltját, fontosabbnak tartják a szociális érzékenységét, a közösség iránti elkötelezettségét. Mindezek okán személyében élvezi azok, közöttük több helyi értelmiségi és a gazdasági elit támogatását is, akik egyébként a jobboldali radikalizmust elutasítanák. Ez a támogatottság a menekültválság idején jelentősen megnőtt, „nélküle ezek megettek volna benünnket” - fogalmazott egy helyi lakos. 
Egy politikai alternatíva és közéleti aktivitás nélküli helyi közeg kiválóan alkalmas volt arra, hogy a radikális szcéna korábbi főszereplője szélesebb társadalmi támogatottságra tegyen szert. Ebbe az irányba tartó törekvéseit 2016 nyarán elismerés koronázta. Mig korábban kölcsönösen az egymástól való távolságukat hangsúlyozták, 2016 nyarán a Jobbik elnökének javaslatára elvállalta a párt alelnöki jelölését, amit a tagság nagy többséggel jóvá is hagyott. Az utcai és radikális, a törvényesség határát számos esetben átlépő politikától a föáram irányába való elmozdulását két mozzanat segítette elö, és mindkettő kötődik a menekültválság idején történő fellépéshez. Az egyik a konzervativ kormányzat radikalizálódása, olyan kormányzati stratégia alkalmazása a menekültválság kezelésére, amelynek belföldön a szélsőjobboldali polgármester volt az ötletgazdája, külföldön pedig elsősorban a szélsőjobboldali populista pártok vagy a konzervatívok rasszista, muszlimellenes csoportjai.

Ez a közeledés természetesen nemcsak a kormányzatot radikalizálta az európai szcénában, hanem a szélsőjobboldali alternativát is szalonképesebbé tette. A folyamatban fontos szerepet játszott a média: egyrészt a polgármester szándékából, aki korábbi egyetemi és lapszerkesztői tapasztalatát eredményesen kamatoztatta a közösségi médián át folyó kommunikációjának megteremtésében. A radikális politika provokatív logikáját követi az, ahogyan a határvédelmet megszervezi és láthatóvá teszi, majd pedig a témát újabb és újabb események generálásával tartja napirenden. Másfelől a nemzetközi média akaratából, aminek figyelme 2015 nyarán Magyarország felé fordult. Ásotthalom útbaesik Röszke és Horgos felé, ezért sok stáb készített itt felvételeket. Ásotthalom polgármestere a látványt szolgáltatja a menekültek elutasításáról és az eurószkepticizmusáról szóló hírekhez és kommentárokhoz, a falu pedig a hátteret.

2016 júniusában Toroczkai Lászlót a párt elnökének javaslatára megválasztották a Jobbik alelnökévé. Reputációját az eredményes és látványos menekült- vagy migránsellenességnek és EUellenességének köszönheti, vagyis országos szinten is az mutatkozik meg, amit Ásotthalmon láttunk: a radikális migráció- és EU-ellenesség társadalmi támogatottsága felülírja a vandalizmussal párosuló radikalizmus népszerűtlenségét. Toroczkai Lászlónak, aki tizenhét évig ki volt tiltva a Magyar Országgyülésböl, és akiröl ezt a tényt a házelnök még 2016 tavaszán is megerősítette, újra van állandó 
belépője, amivel kapcsolatban azt nyilatkozta az újságíróknak: „Nem én változtam, hanem az idök. "25

Hogy ez miként jött létre, arra vonatkozóan további strukturális magyarázatokat keresek felhasználva azokat a megfigyeléseket, amelyek birtokába a terepmunka révén kerültem. A falu lakói számára megélhetést fél évszázadon keresztül a kettős jellegü foglalkoztatás adott, a szegedi és más közeli települések ipara, valamint a helyi mezőgazdaság. A jelentősebb ipari foglalkoztatók megszünése és a megmaradt vállalatok lecsökkent munkaerőigénye az emberek jelentős részét a mezőgazdaságba vezette vissza. A térség mezőgazdasági potenciálját a homokos, nehezen müvelhető termőföld, valamint a tanyai szerkezet jellemzi, amit csak sok munkával és jól szervezett értékesítés mellett lehet jövedelmezővé tenni. Az értékesítés állami tulajdonú cégekkel történt a késő államszocializmus idején, a müvelés pedig részben szövetkezeti, részben saját tulajdonú földeken. A rendszerváltás után az értékesítési piacon szövetkezetek alakultak, amelyek hatékonyan tudták értékesíteni a megtermelt zöldséget és húst a nagy bevásárló központok felé. Ez a rendszer azonban a 2000-es évek elejére összedőlt. A rendszerváltás után épült hatalmas tárolók és hütőházak üresen állnak, a gazdák pedig küzdenek a megélhetésért. A forgalmazásban Ásotthalmon két-három közepes méretü cég tudott talpon maradni, amelyek nagyon alacsony munkabért fizetnek többnyire időszakos foglalkoztással.

Ennek következtében jelentős a munkaerő-fluktuáció: sokan, elsősorban a fiatalok külföldön keresnek munkát, a mezogazdasági csomagoló és forgalmzó kisüzemek pedig jelentős részben külföldi idénymunkásokat foglalkoztatnak. Az aktív munkaerőt alacsony jövedelemszint jellemzi, aminek egyik része a minimálbér (vagy az azzal azonos közmunkásbér, 52-60 ezer Ft/fö/hó), a másik, nagyjából az előzővel azonos része a mezőgazdaságból (állattartásból, háztáji zöldségtermesztésből) származik. Mindez jelentős relatív státuszcsökkenést eredményezett, továbbá egyre növekvő bizonytalanságot a jövedelem és a foglalkoztatás területén. $\mathrm{Az}$ elégedetlenségnek fontos eleme az idősebb korosztály nosztalgikus

\footnotetext{
${ }^{25}$ http://24.hu/belfold/2016/06/15/toroczkai-orul-hogy-visszakerult-aparlamentbe/
}

REGIO 24. évf. (2016) 4. szám 5-32. 
emlékezete az államszocializmusról, aminek intézményei ebben a térségben kb. másfél évtizeddel túlélték a rendszer bukását.

Chris Hann egy közelmúltban megjelent cikkében, amelyben hasonló témában ír egy közeli településről (Tázlár), „overheated underdogs”, vagyis a feltüzelt megalázottak metaforát alkalmazza azoknak a társadalmi csoportoknak a leírására, amelyeket a posztszocialista félperifériás kapitalizmus a vidéki Magyarországon reménytelen helyzetbe sodort. A késő szocializmus biztonságához képest az agrártermelésből élő magyarországi népesség a rendszerváltás és az uniós csatlakozás vesztesének gondolja magát, és ez a percepció valószínüleg nem áll távol a társadalmi struktúrák valóságától. Chris Hann (egy korábbi elemzésünkkel egybecsengően ${ }^{26}$ ) ezzel magyarázza a szociális bizonytalanságból és csalódottságból fakadó szimpátiát minden olyan politikával, amely az euroszkepticizmussal, a nacionalizmussal és az idegenek bünbakként való kezelésével egy időben operál. ${ }^{27}$

A megállapítás Ásotthalom esetében igazolható, amiként az a mechanizmus is, amiről az elméleti bevezetőben azt írtam: általános félelmek projektálódnak az ellenségről szóló diskurzusokra. Az ellenség lefokozását és megsemmisítését megvalósító performatív aktusok pedig a kisemmizettséggel szembeni fellépésként is olvasandók. Chris Hann a helyi strukturális viszonyokat a globális és Európai Unión belüli egyenlőtlenségek rendszerében értelmezi. Megállapításai érvényesek Ásotthalmon is. Kutatásunk a strukturális diagnózist a diskurzusok hatalmának és mechanizmusainak leírásával egészítette ki: rámutattunk, hogy miként történik meg a félelmek kontroll alá vonása, és az miként függ össze az ellenség dehumanizálásáról és elpusztításáról szóló hétköznapi diskurzussal. Továbbá azt mutattuk be, hogy az idegenekkel kapcsolatban a nyilvánosság különböző szintjein kommunikált félelem és különbségtétel hogyan fogalmazódott azokra a kulturális előzményekre támaszkodva, amelyek a xeno-rasszizmust (az idegenek ellenségként való megjelenítését, az ellenség lefokozását és megsemmisítését) elfogadhatóvá tették. Végül amellett is érveltünk, hogy a xenorasszizmus hegemón helyzetbe úgy került, hogy kizárta az érzékelés

${ }^{26}$ Feischmidt Margit - Szombati Kristóf: Understanding the rise..., i. m., 2016.

${ }^{27}$ Hann, Chris: Overheated Underdogs..., i. m., 2016. 
primér módjaira épülő beszédmódok, az idegen emberekkel való találkozásokból származó személyes tapasztalatok bekerülését a közbeszédbe, amelyek az idegenség empatikus megközelítésének irányába mutatnának.

\section{Felhasznált irodalom}

Agamben, Giorgio: State of Exception. Chicago University Press, 2005.

Ásotthalom község önkormányzat települési esélyegyenlőségi programja, 2008.

Buzan, Barry - de Wilde, Jaap - Wæver, Ole: Security: A New Framework for Analysis. Boulder, Colo.: Lynne Rienner Pub, 1998.

Esélyegyenlöségi program, 2008.

http://asotthalom.hu/regi/15\%2520-

\%2520Es\%25c3\%25a9lyegyenl\%25c5\%2591s\%25c3\%25a9gi\%

2520Program\%2520\%2520elfogad\%25c3\%25a1safb99.pdf?type

=file\&id=2995 (Utolsó letöltés: 2016-09-10)

Fassin, Didier: Policing Borders, Producing Boundaries. The Governmentality of Immigration in Dark Times. In: Annual Review of Anthropology, 2011, Vol. 40, 213-226.

Feischmidt Margit - Glózer Rita - Ilyés Zoltán - Kasznár Veronika Katalin - Zakariás Ildikó: Nemzet a mindennapokban: Az újnacionalizmus populáris kultúrája. Budapest: L’ Harmattan, 2014.

Feischmidt Margit - Hervik, Peter: Mainstreaming the Extreme: Intersecting Challenges from the Far Right in Europe. In: Intersections. EEJSP 2015/1, 1-15.

Feischmidt Margit - Szombati Kristóf: Understanding the rise of the far right from a local perspective: Structural and cultural conditions of ethno-traditionalist inclusion and racial exclusion in rural Hungary. In: Identities. Global Studies in Culture and Power, 2016, vol. 1. , 1-19. 
Fekete, Liz: The Emergence of Xeno-racism. In: Race \& Class, 2001, vol. 43 no. 2, 223-240.

Hann, Chris: Overheated Underdogs: Civilizational Analysis and Migration on the Danube-Tisza Interfluve. In: History and Anthropology, 2016/5, 602-616.

Huysman, Jef (2000): The European Union and the Securitization of Migration. In: JSMS: Journal of Common Market Studies, 38., 751-777.

Szalai András - Göbl Gabriella: Securitizing Migration in Contemporary Hungary. Working Paper. CEU Center for EU Enlargement Studies, 2015.

Steuter, Erin - Wills, Deborah: The vermin have struck again': dehumanizing the enemy in post 9/11 media representations. In: Media, War \& Conflict, August 2010, vol. 3 no. 2, 152-167.

Tárki Omnibusz 2014-2016. http://www.tarki.hu/hu/news/2016/kitekint/20160404_idegen.htm l (Utolsó letöltés: 2016-11-04)

Wodak, Ruth - Delanty, Gerard - Jones, Paul: Introduction : migration, discrimination and belonging in Europe. In: Delanty, Gerard - Jones, Paul - Wodak, Ruth (eds): Identity, belonging and migration. Liverpool: Liverpool University Press, 2008, 1018.

Wodak, Ruth - KhosraviNik, Majid: Dynamics of Discourse and Politics in Right-wing Populism in Europe and Beyond: An Introduction. In: Wodak, Ruth - KhosraviNik, Majid - Mral, Brigitte (eds.): Rightwing Populism in Europe: Politics and Discourse. London: Bloomsbury Academic, 2013, xvii-xxviii. 